\title{
Removal of Lead and Chromium from Aqueous Solution onto Flamboyant (Delonix regia) Pod Activated Carbon
}

\author{
S. I. Mustapha ${ }^{1 *}$, L. T. Adewoye ${ }^{1}$, F. A. Aderibigbe ${ }^{1}$, M. H. Alhaji ${ }^{2,3}$, M. I. Adekola ${ }^{1}$, I. A. Tijani ${ }^{1}$ \\ ${ }^{1}$ Department of Chemical Engineering, University of Ilorin, Ilorin, Nigeria. \\ ${ }^{2}$ Nigerian Institute of Leather and Science Technology, Zaria, Nigeria. \\ ${ }^{3}$ Department of Chemical Engineering and Energy Sustainability, Universiti Malaysia Sarawak (UNIMAS), Kota \\ Samarahan, Malaysia.
}

\begin{abstract}
The contamination of water by potentially toxic elements is considered a global problem. It calls for a safe, economic and technological approach in order to curb and prevent the devastating effect of the menace on both human and the aquatic life. In the light of this background, the adsorption potential of flamboyant pod activated carbon (FPAC) for the removal of chromium and lead from aqueous solution was studied. The effect of contact time, $\mathrm{pH}$, initial concentration as well as adsorbent dosage on the removal efficiency of both metal ions was investigated via batch adsorption. Characterization of the FPAC adsorbent was done using Brunaur Emmett Teller and Fourier transform infrared spectroscopy. The maximum adsorption capacity $\mathrm{Q}_{\mathrm{e}}$ was found to be 34.48 and $16.13 \mathrm{mg} / \mathrm{g}$ for $\mathrm{Pb}$ (II) and Cr (VI), respectively. The Langmuir isotherm model showed a better fit to the equilibrium data than the Freundlich isotherm model. The mechanism of adsorption for both metal ions onto the FPAC agrees well with pseudo second order kinetic model. The results showed that FPAC has excellent adsorption properties and thus can be used as an effective low-cost adsorbent for the removal of lead and chromium ions from aqueous solution.
\end{abstract}

KEYWORDS: Flamboyant pod, activated carbon, adsorption, lead, chromium.

[Received July 5 2017; Revised August 29 2017; Accepted October 3 2017]

\section{INTRODUCTION}

The pollution of water by the presence of toxic heavy metals has been a topic of global concern among environmental experts. The spontaneous increase in the pollution of water by toxic heavy metal has been attributed to the breakthrough in the advancement of technologies for industrial expansions (Jimoh et al, 2012). Lead and chromium are among the priority toxic pollutants present in wastewaters which are released to the environment through various industrial operations. The main industrial sources of toxic metals in waste water include; metal finishing, electroplating, metallurgical, tannery, chemical manufacturing, mining, battery manufacturing industries and textile industries (Deepa and Suresha, 2014; Olayinka et al, 2009).

Lead and chromium are considered among the top sixteen toxic pollutants whose exposure is carcinogenic to both humans and aquatic animals (Choudhary et al, 2015). They have adversely affected the human health and cause many diseases and allergies such as encephalopathy seizures, mental retardation, anaemia, dermatitis, severe harm to kidneys, sensory system, and reproductive system (Barbooti, 2015; Dargahi et al, 2016). The maximum allowable limits of lead and chromium in wastewater as indicated by the United States Environmental Protection Agency (USEPA) are 0.1

*Corresponding author's e-mail address: mustapha.si@unilorin.edu.ng $\mathrm{mg} / \mathrm{l}$ and $1.0 \mathrm{mg} / \mathrm{l}$, respectively (Qaiser et al, 2009). As a result of the highly toxic nature of these metals even at low concentrations, there is increasing interest in the development of techniques for their removal from contaminated waters prior to their discharge into the environment.

The adsorption phenomenon is one of the physicochemical treatment processes observed to be effective for heavy metals removal from aqueous solutions. This technology has been widely preferred to other conventional methods such as ion - exchange, chemical precipitation, electro dialysis, membrane separations, reverse osmosis and solvent extraction in the removal of pollutants from wastewater due to its cost effectiveness, simple to design, ease of operation, availability and environmental friendliness (Adebisi et al, 2017). Various adsorbents such as clay mineral (Barbooti, 2015), activated carbons from agricultural waste materials (Amarasinghe and Williams, 2007; Choudhary et al, 2015; Garba et al, 2016; Olayinka et al, 2009; P. Sarma et $a l$, 2015), magnesium oxide nanoparticles (Dargahi et al, 2016), vegetable waste biomass (Nadeem et al, 2014) as well as biological adsorbents (Ali and Alrafai, 2016; Deepa and Suresha, 2014; Lima et al, 2013) have been reported in the literature for lead and chromium removal from wastewater.

These adsorbents have been found to be effective for the removal of targeted pollutants with removal efficiencies ranging from 70 to $99.9 \%$ at varied adsorption process doi: http://dx.doi.org/10.4314/njtd.v14i2.4 
conditions. During the past few decades, considerable attention has been devoted to the development of unconventional materials such as agricultural waste materials for the removal of various pollutants from wastewater due to their abundant nature, selectivity, high adsorption capacity, and easy regeneration (Zhou et al, 2015).

In spite of the good performance of these adsorbents in batch adsorption process, their application at the pilot and industrial scale columns are still very challenging. Developing cost effective adsorbents that can work at conditions such as $\mathrm{pH}$ 7.0, normal temperature with short contact time will be a logical approach to tackling the challenges of transferring the batch mode adsorption conditions to column operations (Ali et al, 2012). Besides, a single adsorbent cannot be effectively used for the removal of all kind of pollutants.

The capacity of adsorbents depends largely on the type of starting material or precursor, processing method, quantity and the preparation conditions (Zhou et al, 2015). Although some works have been reported on the development of adsorbents from agricultural waste materials; however, there is still need for further research on the potential of other available agricultural waste material toward the complete removal of targeted pollutants with the capability to work at column operations.

Flamboyant pods (Delonix regia), a blooming tree species from the Fabaceae family, is known for its fern-like leaves and colourful display of flowers. After a period of maturation, the pods gradually fall off the trees and large quantities of the pods generated constitute environmental nuisance. Conversion of these low-value agricultural wastes (flamboyant pod) into useful material that can remove toxic heavy metals from wastewater would constitute a significant contribution to the search for cheaper adsorbent materials.

Hence, the study's aim was to evaluate the efficiency and effectiveness of sulphuric acid activated flamboyant pod for the removal of lead and chromium ion from aqueous solution. Consequently, the effects of various adsorption process factors such as contact time, $\mathrm{pH}$, initial metal ion concentration and adsorbent dosage were investigated via batch adsorption process. Also, the adsorption isotherms and kinetics parameters were evaluated and reported.

\section{MATERIALS AND METHODS}

\section{A. Preparation of Adsorbent}

Flamboyant pods were collected from different locations within the University of Ilorin, Kwara State, Nigeria. The collected materials were completely washed with distilled water in order to remove dust and other adhering impurities. The washed flamboyant pods were dried at $80{ }^{\circ} \mathrm{C}$ for $24 \mathrm{hrs}$, ground and separated using sieve size of $225 \mu \mathrm{m}$. The uniform particle size biomaterial was subjected to carbonization process in a muffle furnace at a rate of 20 ${ }^{\circ} \mathrm{C} /$ min from room temperature to $500{ }^{\circ} \mathrm{C}$ and maintained at this temperature for 1.5 hours (Vargas et al, 2011). A sample $(400 \mathrm{~g})$ of the calcined flamboyant pod was soaked in an excess of $0.2 \mathrm{M} \mathrm{H}_{2} \mathrm{SO}_{4}$ (purity 85\%) solution for 24 hours.
This was then separated using sieve size of $65 \mu \mathrm{m}$ and rinsed with distilled water to obtain a $\mathrm{pH}$ of 7 ; it was oven dried at $110^{\circ} \mathrm{C}$ for $3 \mathrm{hrs}$ and finally packaged in an airtight container for further use. The carbon prepared from flamboyant pods and activated with sulphuric acid was labelled as FP and FPAC, respectively. All the chemicals and reagents utilized were of analytical grade. Distilled water was used for all experimental work including the preparation aqueous solutions of lead and chromium metal ions. The desired $\mathrm{pH}$ of the aqueous solutions was adjusted using $0.1 \mathrm{M} \mathrm{NaOH}$ and $0.2 \mathrm{M} \mathrm{H}_{2} \mathrm{SO}_{4}$.

\section{B. Preparation of Aqueous Solution}

The stock solutions of $\mathrm{Cr}$ (VI) and $\mathrm{Pb}$ (II) metal ions of $1000 \mathrm{mg} / \mathrm{L}$ concentrations were prepared by dissolving, $2.827 \mathrm{~g}$ of $\mathrm{K}_{2} \mathrm{Cr}_{2} \mathrm{O}_{7}$ (Sigma - Aldrich) and $1.6 \mathrm{~g}$ of $\mathrm{Pb}\left(\mathrm{NO}_{3}\right)$ (Merck Germany), respectively in one litre of distilled water. Subsequently, the stock solutions were further diluted to obtain working solutions of the desired initial concentrations of lead (II) and chromium (VI).

\section{Characterization of Adsorbent}

The Brunaur Emmett Teller (BET) and Fourier transform infrared spectroscopy (FTIR) techniques were used to characterize the prepared adsorbent. The surface area and porosity measurement of the FP and FPAC were carried out using Quantachrome NOVA 4200e UK, surface area and pore size analyzer. The sample in the form of powder was loaded in a bulb ended quartz tube and heated in the furnace to about $350{ }^{\circ} \mathrm{C}$ for outgassing under the flow of liquid nitrogen for about 8 hours in order to remove moisture and contaminants. Fourier transform infrared (FTIR) spectroscopy technique was used to establish the presence of surface functional groups responsible for the lead and chromium adsorption. The FTIR analyses before and after metal ion adsorption were carried out on the samples using Perkin - Elmer spectrum with a resolution of $4 \mathrm{~cm}^{-1}$ in the range of $4000-500 \mathrm{~cm}^{-1}$.

\section{Adsorption Experiments}

Batch adsorption studies were conducted to examine the effect of solution $\mathrm{pH}$, contact time, metal ion initial concentration, and adsorbent dosage on the removal of lead and chromium ion onto FPAC by studying one of the factors at a time and keeping other factors fixed. Different doses of adsorbents ranging from $10-50 \mathrm{mg}$ were separately mixed with $25 \mathrm{~mL}$ of aqueous solution put into $100 \mathrm{~mL}$ Erlenmeyer flasks containing different initial concentrations (between 5$25 \mathrm{mg} / \mathrm{L}$ ) for both chromium and lead ion. The $\mathrm{pH}$ of the solution was varied between the $\mathrm{pH}$ value of 5 and 9 using either $0.1 \mathrm{M} \mathrm{NaOH}$ or $0.2 \mathrm{M} \mathrm{H}_{2} \mathrm{SO}_{4}$.

The mixture was shaken constantly using an orbit shaker at $140 \mathrm{rpm}$ speed for varying contact time interval from 20 to 70 mins. The mixture was then filtered and the residual concentration of metal ions was analyzed using Atomic Absorption Spectrophotometer (AAS) (BUCK Scientific ACCUSYS 211). The percentage removal of the lead and chromium ions was determined by using eqn (1). 


$$
\% \text { Removal }=\frac{\left(C_{o}-C_{e}\right)}{C_{o}} * 100
$$

Where; $\mathrm{C}_{\mathrm{o}}$ and $\mathrm{C}_{\mathrm{e}}(\mathrm{mg} / \mathrm{L})$ are the concentrations of $\mathrm{Pb}$ (II) and $\mathrm{Cr}(\mathrm{VI})$ in the aqueous solution at initial stage and at equilibrium, respectively.

The equilibrium amount $\left(\mathrm{Q}_{\mathrm{e}}\right)$ of lead and chromium ion removed per mass of adsorbent was evaluated using the equation 2:

$$
Q_{e}=\frac{\left(C_{o}-C_{e}\right) V}{W}
$$

Where; $\mathrm{Q}_{\mathrm{e}}\left(\mathrm{mg} \mathrm{g}^{-1}\right)$ is the amount of metal ion adsorbed per unit mass of adsorbent at equilibrium. V (L) is the volume of the solution and W (g) is the mass of FPAC used. Each of the experiment was repeated twice and the mean values considered.

\section{i. Effect of Contact Time}

In order to investigate the effect of contact time, $25 \mathrm{~mL}$ of the aqueous solution containing $5 \mathrm{mg} / \mathrm{L}$ of initial metal concentration was taken into $100 \mathrm{~mL}$ Erlenmeyer flasks and $10 \mathrm{mg}$ of the FPAC adsorbent was added. The mixture was shaken constantly using an orbit shaker at $140 \mathrm{rpm}$ speed for varying contact time from 20 to 70 mins at 10 mins interval. At the end of each contact time period, the mixture was filtered and the residual of lead and chromium concentrations in solution were determined using AAS.

\section{ii. Effect of $p H$}

The effect of $\mathrm{pH}$ on adsorption of the metals was investigated by adding $10 \mathrm{mg}$ of FPAC to $25 \mathrm{~mL}$ of the aqueous solution containing $5 \mathrm{mg} / \mathrm{L}$ of initial metal ion concentration. The $\mathrm{pH}$ of the solution was varied between the $\mathrm{pH}$ value of 5 and 9 using either $0.1 \mathrm{M} \mathrm{NaOH}$ or $0.2 \mathrm{M} \mathrm{H}_{2} \mathrm{SO}_{4}$. The blend was shaken for 30 mins and then filtered and the amount of metal ion adsorbed was determined.

\section{iii. Effect of Initial Concentration}

In order to investigate the effect of concentration on the adsorption of metal ion, $10 \mathrm{mg}$ of FPAC adsorbent was added to $25 \mathrm{~mL}$ of the metal solutions of different initial concentrations (between 5-25 mg/L) for both chromium and lead ion. The resultant solution with the adsorbent in the flask was shaken for $30 \mathrm{mins}$ at $140 \mathrm{rpm}$, filtered and analyzed.

\section{iv. Effect of Adsorbent Dosage}

In order to study the effect of adsorbent dose on the adsorption of lead and chromium, various doses of adsorbents ranging from $10-50 \mathrm{mg}$ were separately mixed with $25 \mathrm{~mL}$ of aqueous solution put into $100 \mathrm{~mL}$ Erlenmeyer flasks containing $25 \mathrm{mg} / \mathrm{L}$ of initial metal ion concentration. The mixture was shaken constantly using an orbit shaker for 30 minutes at $140 \mathrm{rpm}$, filtered and the residual chromium and lead concentrations in solution were determined.

\section{E. Adsorption Isotherm}

The equilibrium relationship between the adsorbate concentration in the solution and on the surface of the adsorbent at a specified condition is described through adsorption isotherm models. The adsorption isotherms of $\mathrm{Pb}$ (II) and $\mathrm{Cr}$ (VI) ions onto FPAC were determined at different concentrations ranging from 5 to $25 \mathrm{mg} / \mathrm{L}$ on a fixed amount of adsorbent (FPAC). Langmuir and Freundlich isotherm models were used to describe the equilibrium characteristic of this adsorption study.

\section{$i$. The Langmuir isotherm model}

Langmuir isotherm assumes monolayer adsorption on a uniform surface with a finite number of adsorption sites. The linearized form of the Langmuir isotherm model (Langmuir, 1918) is given as:

$$
\frac{C_{e}}{Q_{e}}=\frac{1}{b Q_{\max }}+\frac{C_{e}}{Q_{\max }}
$$

Where; $Q_{\max }(\mathrm{mg} / \mathrm{g})$ is the maximum monolayer adsorbent capacity and $b(\mathrm{~L} / \mathrm{mg})$ is the Langmuir constant related to the energy of adsorption.

\section{ii. The Freundlich isotherm model}

Freundlich isotherm assumes heterogeneous adsorption surface and the linearized form of the Freundlich model (Clayton, 1926) is given as:

$$
\ln Q_{e}=\ln k_{f}+(1 / n) \ln C_{e}
$$

Where; $\mathrm{k}_{\mathrm{f}}(\mathrm{L} / \mathrm{g})$ and $\mathrm{n}$ are the Freundlich isotherm parameters which reveal the capacity and intensity of the adsorption, respectively. The adsorption process is identified to be physical when $n>1$, chemical when $n<1$ or linear when $\mathrm{n}=1$. Generally, $\mathrm{n}>1$ suggests favourable adsorption (Garba et al, 2016).

\section{F. Adsorption Kinetics}

Pseudo first-order and pseudo second order kinetic models were used to analyze the rate and mechanism of adsorption of the metal ions onto FPAC.

\section{i. The Pseudo First Order Kinetic Model}

The mathematical expression in linearized form for the pseudo first order model (Lagergren and Svenska, 1898) is given as:

$$
\log \left(Q_{e}-Q_{t}\right)=\log Q_{e}-\frac{k_{1}}{2.303} t
$$

Where; $\mathrm{k}_{1}\left(\mathrm{~min}^{-1}\right)$ is the pseud-first order rate constant, $\mathrm{Q}_{\mathrm{e}}$ $(\mathrm{mg} / \mathrm{g})$ and $\mathrm{Q}_{\mathrm{t}}(\mathrm{mg} / \mathrm{g})$ are the amount of metal ion adsorbed per unit mass of FPAC adsorbent at equilibrium and at time $\mathrm{t}$ (min), respectively. 


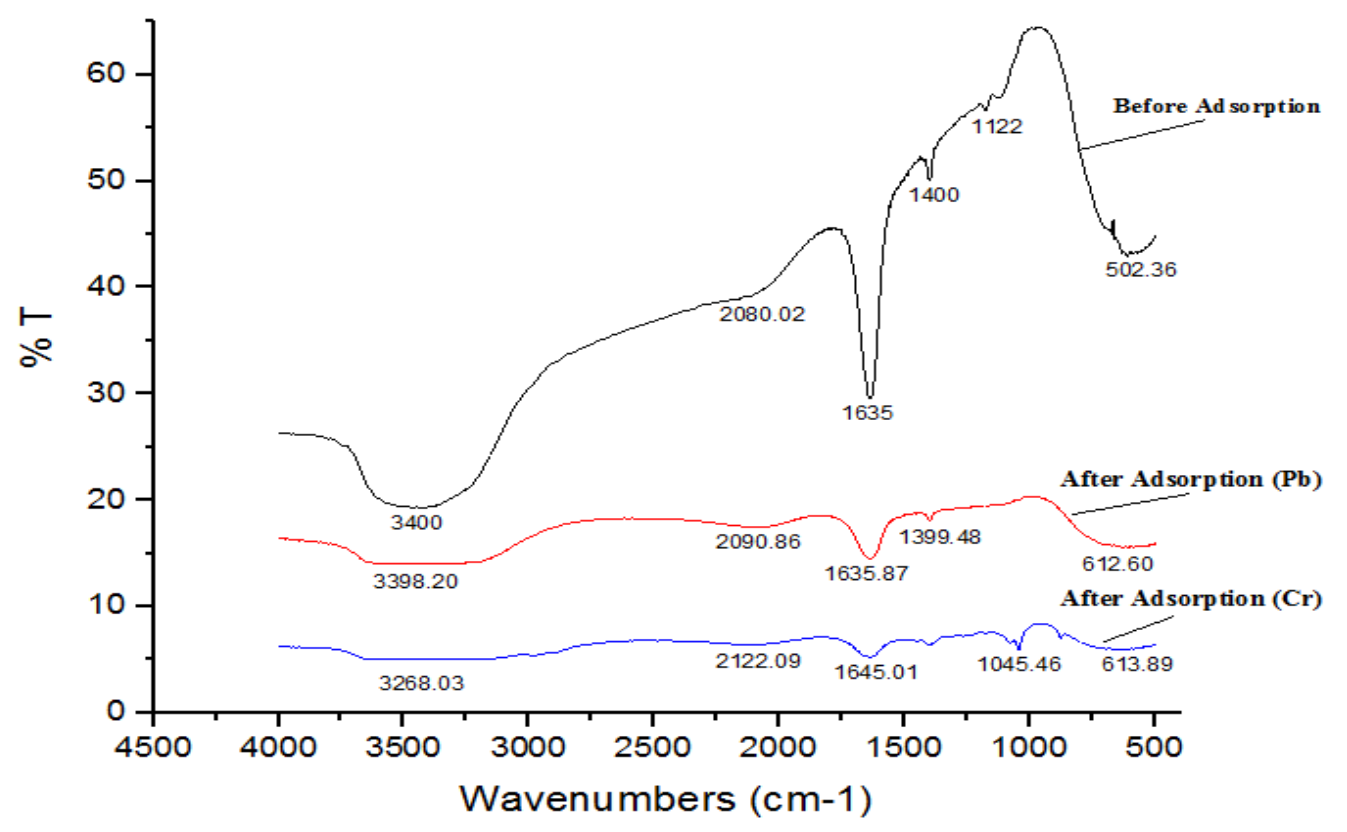

Figure 1: FT-IR of FPAC before and after Adsorption of the Metal Ions.

\section{ii. The Pseudo Second Order Kinetic Model}

The mathematical expression of pseudo second order model in linearized form (Ho and McKay, 1999) is given as:

$$
\frac{t}{Q_{t}}=\frac{1}{k_{2} Q_{e}^{2}}+\frac{1}{Q_{e}} t
$$

Where; $\mathrm{k}_{2}(\mathrm{~g} / \mathrm{mg} \min )$ is the model rate constant.

\section{RESULTS AND DISCUSSION}

\section{A. Characterization of Adsorbent}

The Brunauer Emmett Teller (BET) analysis of the calcined flamboyant pod (FP) and the sulphuric acid activated flamboyant pod (FPAC) are presented in Table 1. The BET surface area result as shown in Table 1 increased from 379.13 $\mathrm{m}^{2} / \mathrm{g}$ to $719.34 \mathrm{~m}^{2} / \mathrm{g}$ as a result of the effect of acid activation on the calcined flamboyant pod. The high value of surface area obtained is an indication that the FPAC may have better metal ion uptake capacity. This can be compared with the surface area of some commercial activated carbons found in the literature (Auta and Hameed, 2011; Ozcan et al, 2004). Also, based on the results obtained, both FP and FPAC adsorbents were found to be mesoporous $(2-50 \mathrm{~nm})$ in nature with the average pore diameter $\mathrm{Dp}$ of $3.17 \mathrm{~nm}$ and $2.94 \mathrm{~nm}$, respectively.

Table 1: The BET Characterization of the Adsorbent.
The results of the FT- IR study carried out and the spectra are shown in Figure 1. The FT-IR spectra for the FPAC before adsorption, after adsorption of lead (II) and chromium (VI), are shown in Figure 1. The broad peak observed at $3400 \mathrm{~cm}^{-1}$ corresponds to $\mathrm{O}-\mathrm{H}$ stretching and $\mathrm{N}$ $\mathrm{H}$ stretching presenting amino group (Krishnie et al, 2011; Qaiser et al, 2009).

A medium peak assigned as alkynes with stretches of $\mathrm{C} \equiv \mathrm{C}$ was found around $2080.02 \mathrm{~cm}^{-1}$. The sharp peak located at $1635 \mathrm{~cm}^{-1}$ suggests the character of a typical carbonyl group $(\mathrm{C}=\mathrm{O})$ stretching from aldehydes and ketones. The presence of $\mathrm{O}-\mathrm{H}$, alkynes stretches of $\mathrm{C} \equiv \mathrm{C}$, along with the carbonyl group, confirms the presence of carboxylic acid groups in the adsorbent (Choudhary et al, 2015).

The peaks at $1400 \mathrm{~cm}^{-1}$ and $1122 \mathrm{~cm}^{-1}$ are associated with the $\mathrm{C}-\mathrm{H}$ and $\mathrm{C}-\mathrm{O}$ bonds. The FPAC after adsorption of $\mathrm{Cr}$ (VI) had its $\mathrm{O}-\mathrm{H} / \mathrm{N}-\mathrm{H}$ at the broad peak of $3268.03 \mathrm{~cm}^{-1}$ with $\mathrm{C}-\mathrm{H}$ stretching vibrations of methyl radicals at the signal of $2980.46 \mathrm{~cm}^{-1}$. After lead and chromium adsorption, the $\mathrm{O}-\mathrm{H}, \mathrm{N}-\mathrm{H}$, carbonyl and carboxylic functional groups were found on the FPAC with significant shifts in the bands suggesting that chemical interactions between the metal ions and the functional group occur on the FPAC surface (Deepa and Suresha, 2014; Duran et al, 2011; Ozcan et al, 2004; Qaiser et al, 2009). Hence, the main functional groups present in the FPAC adsorbent responsible for the adsorption activities of both lead and chromium are $\mathrm{O}-\mathrm{H}, \mathrm{N}-\mathrm{H}$, carbonyl and carboxylic groups.

\begin{tabular}{lcccc}
\hline Sample & $\begin{array}{c}\text { BET surface area, } \\
\mathrm{S}_{\mathrm{BET}}\left(\mathrm{m}^{2} / \mathrm{g}\right)\end{array}$ & $\begin{array}{c}\text { Micropore surface } \\
\text { area, } \mathrm{S}_{\text {mic }}\left(\mathrm{m}^{2} / \mathrm{g}\right)\end{array}$ & $\begin{array}{c}\text { Micropore volume, } \\
\mathrm{V}_{\text {mic }}\left(\mathrm{cm}^{3} / \mathrm{g}\right)\end{array}$ & $\begin{array}{c}\text { Pore Size, } \mathrm{Dp} \\
(\mathrm{nm})\end{array}$ \\
\hline FP & 379.13 & 346.10 & 0.123 & 3.17 \\
FPAC & 719.34 & 888.40 & 0.316 & 2.94 \\
\hline
\end{tabular}




\section{B. Adsorption Experiments}

\section{i. Effect of Contact Time}

The removal efficiency of $\mathrm{Pb}$ (II) and $\mathrm{Cr}$ (VI) onto FPAC as a function of contact time in the range of $20-70$ mins is shown in Figure 2. The figure reveals that the maximum removal efficiency of $98.4 \%$ and $94.4 \%$ for $\mathrm{Pb}$ and $\mathrm{Cr}$ ions, respectively was achieved within $20-30$ minutes. This rapid adsorption process within the first 30 mins may be attributed to effective contact and availability of active adsorption sites (Choudhary et al, 2015; Jimoh et al, 2012).

After the equilibrium was attained at $30 \mathrm{mins}$, it was followed by a progressive drop in metal uptake. Slow pore intra - particle diffusion of the metal ion to the interior of the adsorbent and the electrostatic hindrance caused by already sorbed metal ion accounts for the subsequent slower sorption rate as the contact time increases. The trend of adsorption observed was $\mathrm{Pb}$ (II) $>\mathrm{Cr}$ (VI) as shown in Figure 2. This may be attributed to that fact that metal ion with smaller ionic radii diffuses faster than metal ion with larger ionic radii (Jimoh et al, 2012). A similar trend was reported by Qaiser $e t$ al (2009) who studied the potential of groundnut hull for the removal of lead (II) and chromium (VI) from wastewater.

\section{ii. Effect of $p H$}

The solution $\mathrm{pH}$ is an important controlling factor in heavy metal adsorption process which affects the surface charge of the adsorbent material, the degree of ionization and the specification of metals in the solution (Choudhary et al, 2015). The $\mathrm{pH}$ of the solution was varied between the $\mathrm{pH}$ value of 5 and 9 and the effect of the $\mathrm{pH}$ on the percentage removal of $\mathrm{Pb}$ and $\mathrm{Cr}$ at initial metal ion concentration of 5 $\mathrm{mg} / \mathrm{L}$, the adsorbent dosage of $10 \mathrm{mg}$ and contact time of 30 min is shown in Figure 3. As shown in the figure, it can be observed that the percentage removal of $\mathrm{Pb}$ increased from $94.5 \%$ to $99.1 \%$ between the $\mathrm{pH}$ of 5 and 6 while the percentage removal of $\mathrm{Cr}$ increased from $91.5 \%$ to $97.3 \%$ between the $\mathrm{pH}$ of 5 and 7 . Further increase in $\mathrm{pH}$ leads to decrease in the percentage removal of both metal ions.

The maximum removal of $97.3 \%$ was attained at $\mathrm{pH}$ of 6.0 for lead (II) whereas, in the case of chromium (VI), the maximum removal of $99.1 \%$ was achieved at $\mathrm{pH}$ of 7.0 . At low $\mathrm{pH}$ values, the competition for binding sites between the metal cations and protons may possibly be responsible for the reduced uptake capacity of the metal. However, with an increase in $\mathrm{pH}$, the negatively charged adsorbent was expected to attract the positively charged lead and chromium ions (Sarma et al, 2015). This electrostatic attraction may possibly be responsible for higher metal uptake at higher $\mathrm{pH}$ than at low $\mathrm{pH}$ value. Although, beyond $\mathrm{pH} 7$, a slight decrease in the metal uptake was observed which might be due to numerous competition between $\mathrm{OH}^{-}$and binding sites of FPAC.

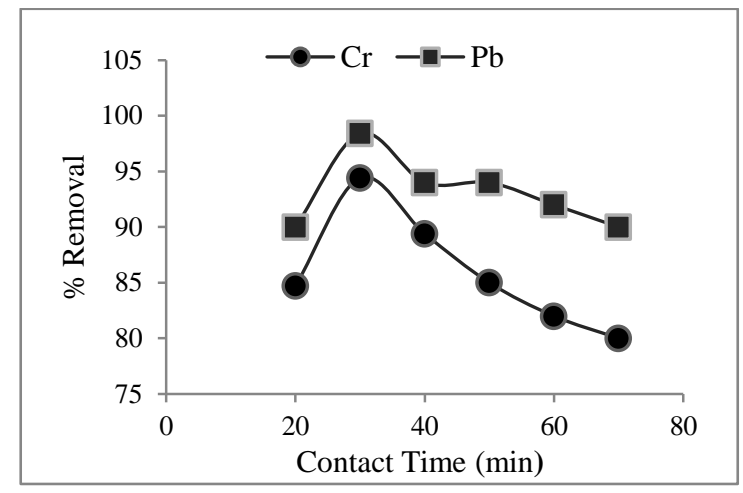

Figure 2: Effect of Contact Time on Adsorption of $\mathrm{Pb} / \mathrm{Cr}$ on FPAC [Ambient Temperature $=30{ }^{\circ} \mathrm{C} ; \mathrm{pH}=7$; Metal ion conc. $=5 \mathrm{mg} / \mathrm{L}$; Adsorbent dosage $=10 \mathrm{mg}$ ].

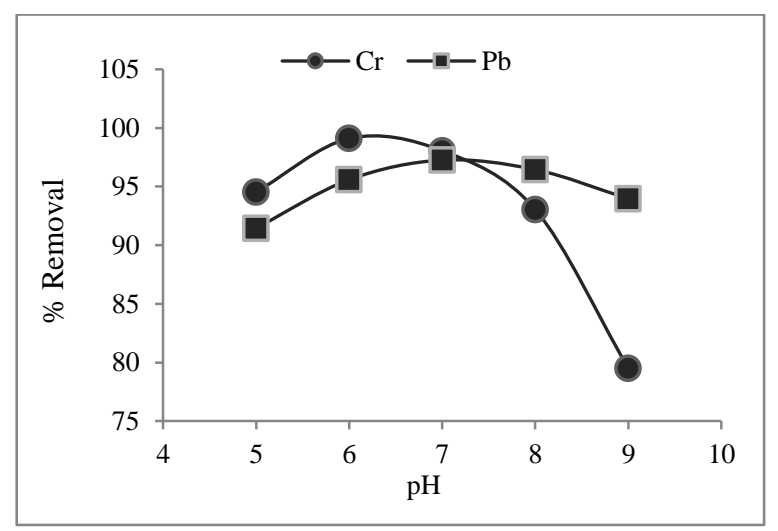

Figure 3: Effect of $\mathrm{pH}$ on Adsorption of $\mathrm{Pb} / \mathrm{Cr}$ on FPAC [Ambient Temperature $=30{ }^{\circ} \mathrm{C}$; Metal ion conc. $=5 \mathrm{mg} / \mathrm{L}$; Adsorbent dosage $=$ $10 \mathrm{mg}$; Contact time $=30 \mathrm{mins}$.

\section{iii. Effect of Initial Concentration}

The effect of initial metal ion concentration on the removal efficiency of FPAC was investigated and presented in Figure 4. The removal efficiency of lead decreased from $97.43 \%$ to $89.77 \%$ with an increase in the metal ion concentration. This can be attributed to the lack of sufficient surface area to accommodate more metal ions thereby leading to competition between metal ions to adsorb on the limited available active site of the adsorbent.

On the other hand, the removal efficiency of chromium increased from $74.76 \%$ to $99.6 \%$ with an initial metal ion concentration increased from $5 \mathrm{mg} / \mathrm{L}$ to $25 \mathrm{mg} / \mathrm{L}$. This shows that more molecules of the chromium ions in solution competed for available binding sites of the adsorbent at higher concentrations than at lower concentrations. These findings agree well with previous studies carried out in similar work (Deepa and Suresha, 2014; Jimoh et al, 2012; Olayinka et al, 2009). 


\section{iv. Effect of Adsorbent Dosage}

The effect of adsorbent dosage in the range of $10 \mathrm{mg}$ to $50 \mathrm{mg}$ at an initial metal ion concentration of $25 \mathrm{mg} / \mathrm{L}, \mathrm{pH}$ of 7 and contact time of 30 min was investigated. As shown in Figure 5, the percentage removal of chromium ion increased from $89.5 \%$ to $99.7 \%$ with an increase in adsorbent dosage from $10 \mathrm{mg}$ to $50 \mathrm{mg}$. This increase in chromium uptake as a result of an increase in adsorbent dosage was due to the availability of more number of active sites on the surface of FPAC for the adsorption of Cr (VI) (Krishna and Swamy, 2011).

A trend that is similar was observed for lead ion adsorption though the percentage removal increased from $92.5 \%$ to $97.2 \%$ as the dosage increases from $10 \mathrm{mg}$ to $30 \mathrm{mg}$ and thereafter decreased to $94.4 \%$ with a further increase in adsorbent dose to $50 \mathrm{mg}$. Thus, the percent adsorption of lead ion increased with the adsorbent dosage and reached an equilibrium value after certain dosage. The reason for the decrease may be due to aggregation or overlapping of the adsorption sites which could lead to an overall decrease in available binding sites (Choudhary et al, 2015; Nethaji and Sivasamy, 2014).

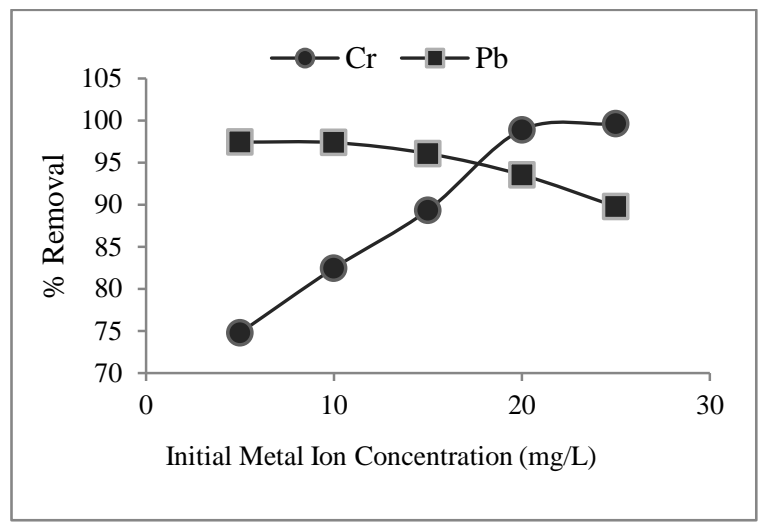

Figure 4: Effect of Initial Metal Ion Concentration on Adsorption of $\mathrm{Pb} / \mathrm{Cr}$ on FPAC [Ambient Temperature $=30{ }^{\circ} \mathrm{C} ; \mathbf{p H}=7$; Adsorbent dosage $=10 \mathrm{mg}$; Contact time $=30 \mathrm{mins}]$.

\section{Adsorption Isotherm}

The results of adsorption studies of $\mathrm{Pb}$ (II) and $\mathrm{Cr}(\mathrm{VI})$ at different concentrations ranging from 5 to $25 \mathrm{mg} / \mathrm{L}$ on a fixed amount of adsorbent are expressed by Langmuir and Freundlich isotherm models.

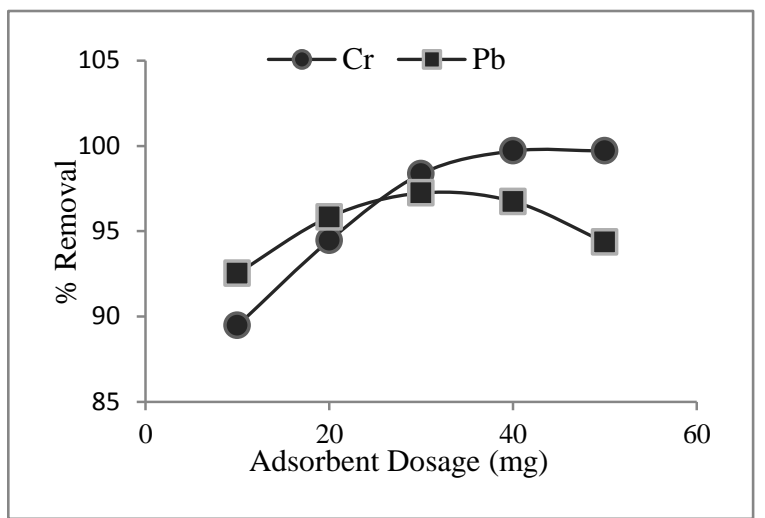

Figure 5: Effect of Adsorbent Dosage on Adsorption of $\mathrm{Pb} / \mathrm{Cr}$ on FPAC [Ambient Temperature $=3{ }^{\circ} \mathrm{C} ; \mathrm{pH}=7$; Metal ion conc. $=25$ $\mathrm{mg} / \mathrm{L}$; Contact time $=\mathbf{3 0}$ mins $]$.

\section{i. The Langmuir isotherm model}

The Langmuir isotherm (Equation 3) was evaluated by plotting $\mathrm{C}_{\mathrm{e}} / \mathrm{Q}_{\mathrm{e}}$ against $\mathrm{C}_{\mathrm{e}}$ and straight lines shown in Figure 6 were fitted by regression for both $\mathrm{Pb}$ (II) and $\mathrm{Cr}$ (VI) adsorption data. The value of $\mathrm{Q}_{\max }$ and $\mathrm{b}$ were evaluated from the slope and intercept of lines in Figure 6 and are presented in Table 2.

The dimensionless separation factor $\left(\mathrm{R}_{\mathrm{L}}\right)$ was used to discuss the essential characteristics of Langmuir model which is given as:

$$
R_{L}=\frac{1}{1+b C_{o}}
$$

Where $\mathrm{C}_{\mathrm{o}}$ is the initial concentration of metal ion $(\mathrm{mg} / \mathrm{L})$ The value of $R_{L}$ determined, gives information about the nature of adsorption.

It indicated the type of Langmuir isotherm to be favourable $\left(0<\mathrm{R}_{\mathrm{L}}<1\right)$, unfavourable $\left(\mathrm{R}_{\mathrm{L}}>1\right)$, linear $\left(\mathrm{R}_{\mathrm{L}}=\right.$ 1) or irreversible $\left(R_{L}=0\right)$.

As shown in Table 2, the values of $R_{L}$ were found to be 0.046 and 0.031 for the concentration of $5 \mathrm{mg} / \mathrm{L}$ of $\mathrm{Pb}$ and $\mathrm{Cr}$ metal ions, respectively.

The values obtained in the range of 0 - 1 which indicates favourable adsorption. As presented in Table 2, the correlation coefficient values for both, $\mathrm{Pb}\left(\mathrm{R}^{2}=0.999\right)$ and $\mathrm{Cr}$ $\left(R^{2}=0.906\right)$ showed very good linearity to both metal ions. This is an indication of a strong positive relationship for the adsorption data.

Table 2: Langmuir and Freundlich Isotherms for Pb (II) and Cr (VI) Adsorption on FPAC.

\begin{tabular}{llllllll}
\hline \multirow{2}{*}{$\begin{array}{l}\text { Metal } \\
\text { Ion }\end{array}$} & \multicolumn{3}{c}{ Langmuir isotherm model } & \multicolumn{3}{c}{ Freundlich isotherm model } \\
\cline { 2 - 7 } & $\mathrm{Q}_{\max }(\mathrm{mg} / \mathrm{g})$ & $\mathrm{b}$ & $\mathrm{R}_{\mathrm{L}}$ & $\mathrm{R}^{2}$ & $\mathrm{k}_{\mathrm{f}}$ & $\mathrm{n}$ & $\mathrm{R}^{2}$ \\
\hline $\mathrm{Pb}$ & 34.48 & 4.14 & 0.046 & 0.999 & 25.30 & 3.28 & 0.945 \\
$\mathrm{Cr}$ & 16.13 & 6.21 & 0.031 & 0.906 & 17.10 & 3.53 & 0.492 \\
\hline
\end{tabular}



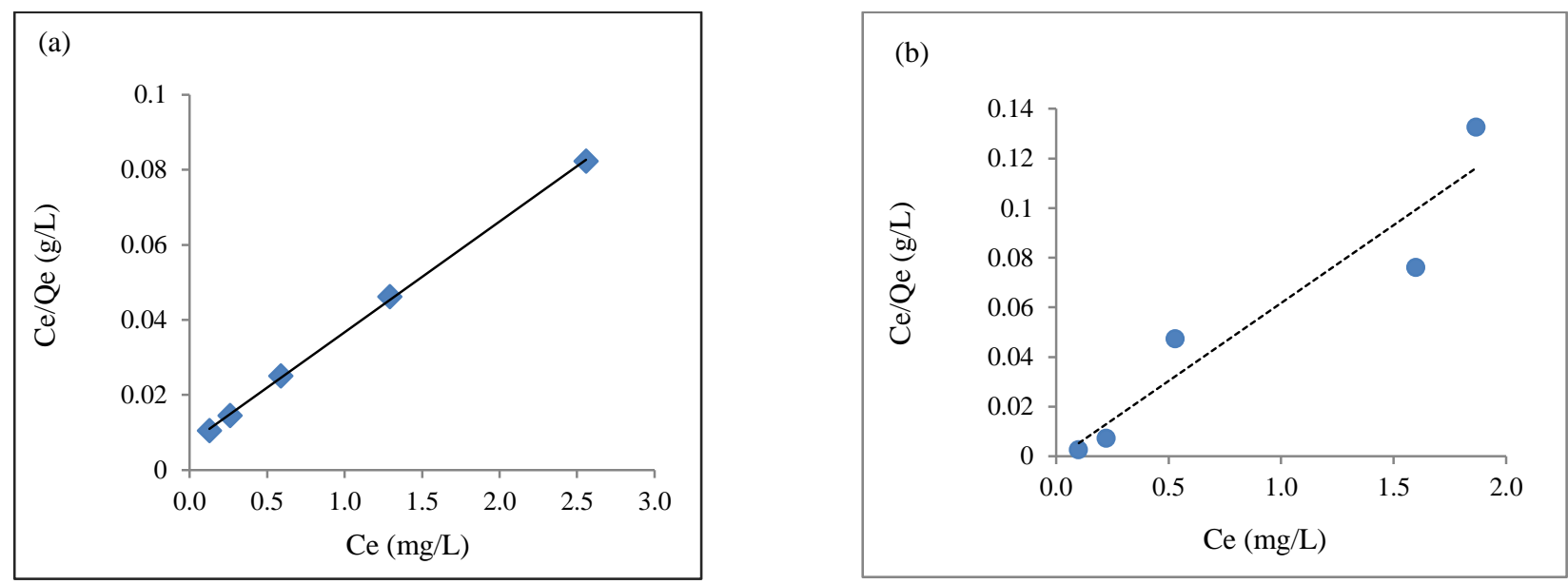

Figure 6: Langmuir adsorption isotherm plot for (a) $\mathrm{Pb}$ (II) (b) $\mathrm{Cr}$ (VI).

Table 3: Comparison of monolayer adsorption of $\mathrm{Pb}$ (II) and $\mathrm{Cr}$ (VI) onto various Adsorbents.

\begin{tabular}{lccl}
\hline \multirow{2}{*}{ Adsorbents } & \multicolumn{2}{c}{$\mathrm{Q}_{\max }(\mathrm{mg} / \mathrm{g})$} & \multicolumn{1}{l}{ References } \\
\cline { 2 - 3 } & $\mathrm{Pb}(\mathrm{II})$ & $\mathrm{Cr}(\mathrm{VI})$ & \\
\hline FPAC & 34.48 & 16.13 & This work \\
Magnesium oxide nanoparticles & 21.78 & 16.44 & (Dargahi et al, 2016) \\
Ficus nitida leaves & - & 21.0 & (I. H. Ali and Alrafai, 2016) \\
Sorghum roots & - & 20.703 & (Choudhary et al, 2015) \\
Vegetablewaste biomass & 0.465 & 1.089 & (Nadeem et al, 2014) \\
Araucaria cookii leaves & 37.03 & - & (Deepa and Suresha, 2014) \\
Groundnut hull & 31.54 & 30.21 & (Qaiser et al, 2009) \\
Biological activated dates stem & 27.03 & - & (Yazid and Maachi, 2008) \\
Ficus religiosa leaves & 37.45 & 26.25 & (Qaiser et al, 2007) \\
Bagasse fly ash & 2.5 & 4.35 & (Gupta and Ali, 2004) \\
\hline
\end{tabular}

The maximum monolayer adsorption capacity $\left(\mathrm{Q}_{\max }\right)$ values of $34.48 \mathrm{mg} / \mathrm{g}$ for lead and $16.13 \mathrm{mg} / \mathrm{g}$ for chromium observed in this study compared well with some other adsorbents reported from literature as shown in Table 3.

\section{ii. The Freundlich isotherm model}

The Freundlich isotherm (Equation 4) was evaluated by plotting $\ln \mathrm{Q}_{\mathrm{e}}$ versus $\ln \mathrm{C}_{\mathrm{e}}$ and straight lines as displayed in Figure 7 were fitted by regression. The Freundlich model constants $\left(\mathrm{k}_{\mathrm{f}}\right.$ and $\left.\mathrm{n}\right)$ values obtained from the slope and intercept of lines in Figure 7 are shown in Table 2.
The $\mathrm{n}$ - values obtained were in the range of 3 to 4 for both metal ions which indicates a physical and favourable adsorption of $\mathrm{Pb}$ and $\mathrm{Cr}$ onto FPAC.

As shown in Table 2, the values of correlation coefficient $\left(\mathrm{R}^{2}\right)$ of both model revealed that the Langmuir isotherm model showed a better fit to the equilibrium data than the Freundlich isotherm model. Thus, the present adsorption of $\mathrm{Pb}$ and $\mathrm{Cr}$ onto FPAC can be interpreted as monolayer adsorption. 

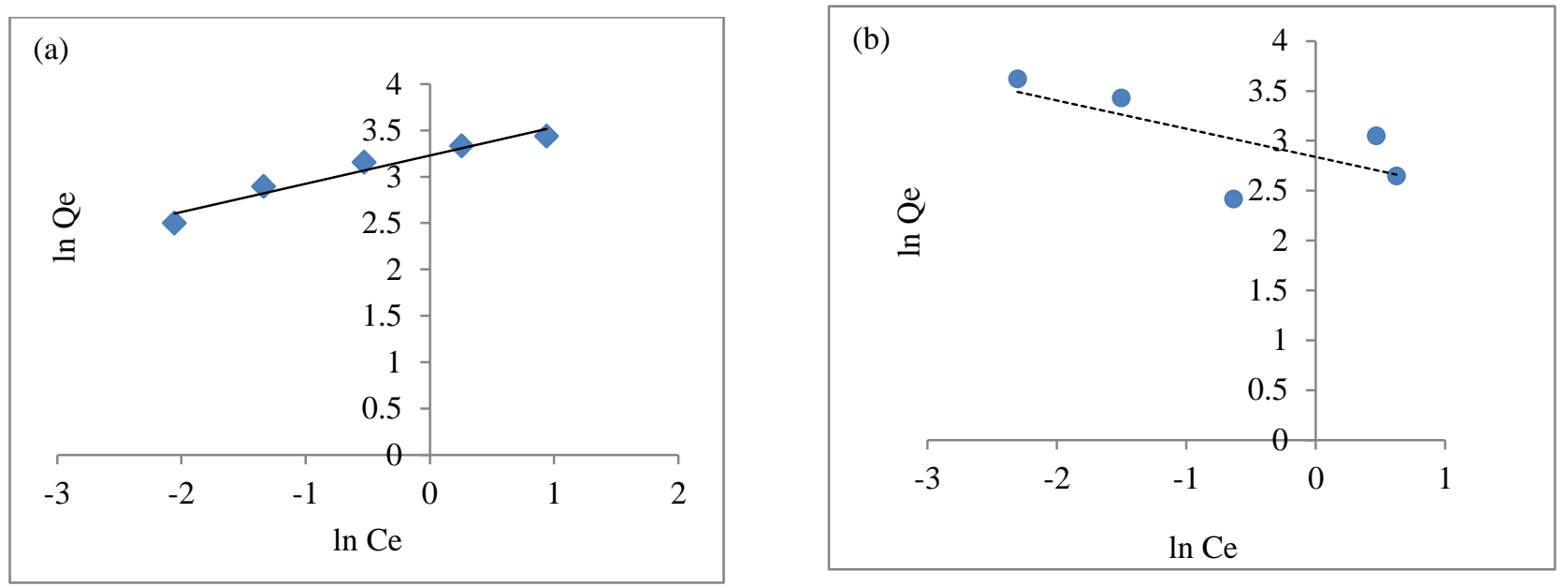

Figure 7: Freundlich adsorption isotherm plot for (a) $\mathrm{Pb}$ (II) (b) $\mathrm{Cr}$ (VI).

\section{Adsorption Kinetics}

Pseudo first-order (Equation 5) and pseudo second order (Equation 6) kinetic models were used to analyze the rate and mechanism of adsorption of the metal ions onto FPAC.

\section{i. The Pseudo First Order Kinetic Model}

The values of $k_{1}$ and $Q_{e}$ were determined from the slope and intercept of lines of the plots of $\log \left(\mathrm{Q}_{\mathrm{e}}-\mathrm{Q}_{\mathrm{t}}\right)$ against ( $\left.\mathrm{t}\right)$ shown in Figure 8 and the respective values were presented in Table 4. The linear plots of $\log \left(Q_{e}-Q_{t}\right)$ versus $t$ gave poorly fitted curves. Also, the values of experimental $Q_{e}$ for both metal ions was observed to differ from the model $\mathrm{Q}_{\mathrm{e}}$ values suggesting the mechanism of the adsorption was not well described by this kinetic model.

\section{ii. The Pseudo Second Order Kinetic Model}

The values of $\mathrm{Q}_{\mathrm{e}}$ and $\mathrm{k}_{2}$ were determined from the slope and intercept of lines of the plots of $t / Q_{t}$ against time (t) as displayed in Figure 9. The Plots of $t / \mathrm{Q}_{t}$ against time $(\mathrm{t})$ gave excellently fitted curves $\left(\mathrm{R}^{2}=0.98\right.$ for $\mathrm{Pb}$ (II); 0.99 for $\mathrm{Cr}$ (VI)). The parameters generated from the plots of pseudo second order kinetic model for the adsorption of $\mathrm{Pb}$ and $\mathrm{Cr}$ on FPAC are presented in Table 4. The value of $Q_{e}$ from the plots for both metal ions (Table 4) conform to the experimental $\mathrm{Q}_{\mathrm{e}}$ indicating that pseudo second order mechanism represented the data more appropriately. The applicability of this model suggested that the adsorption of $\mathrm{Pb}$ (II) and $\mathrm{Cr}$ (VI) onto FPAC was controlled by a chemical reaction between the metal ions and the active sites of the adsorbent.

The FTIR spectra of FPAC (Figure 1) before and after adsorption of $\mathrm{Pb}$ (II) and $\mathrm{Cr}$ (VI) also supported this argument.

Table 4: Pseudo-first order and Pseudo-second order kinetic model parameters for $\mathrm{Pb}$ (II) and $\mathrm{Cr}$ (VI) Adsorption onto FPAC.

\begin{tabular}{|c|c|c|c|c|c|c|}
\hline \multirow[t]{2}{*}{ Metal ion } & \multicolumn{3}{|c|}{ Pseudo - first order parameters } & \multicolumn{3}{|c|}{ Pseudo - second order parameters } \\
\hline & $\mathrm{Q}_{\mathrm{e}}(\mathrm{mg} / \mathrm{g})$ & $\mathrm{k}_{1}\left(\min ^{-1}\right)$ & $\mathrm{R}^{2}$ & $\mathrm{Q}_{\mathrm{e}}(\mathrm{mg} / \mathrm{g})$ & $\mathrm{k}_{2(\mathrm{~g} / \mathrm{mg} \min )}$ & $\mathrm{R}^{2}$ \\
\hline $\mathrm{Pb}$ & 0.176 & 0.020 & 0.10 & 9.901 & 0.016 & 0.98 \\
\hline $\mathrm{Cr}$ & 0.348 & 0.023 & 0.18 & 9.615 & 0.024 & 0.99 \\
\hline
\end{tabular}



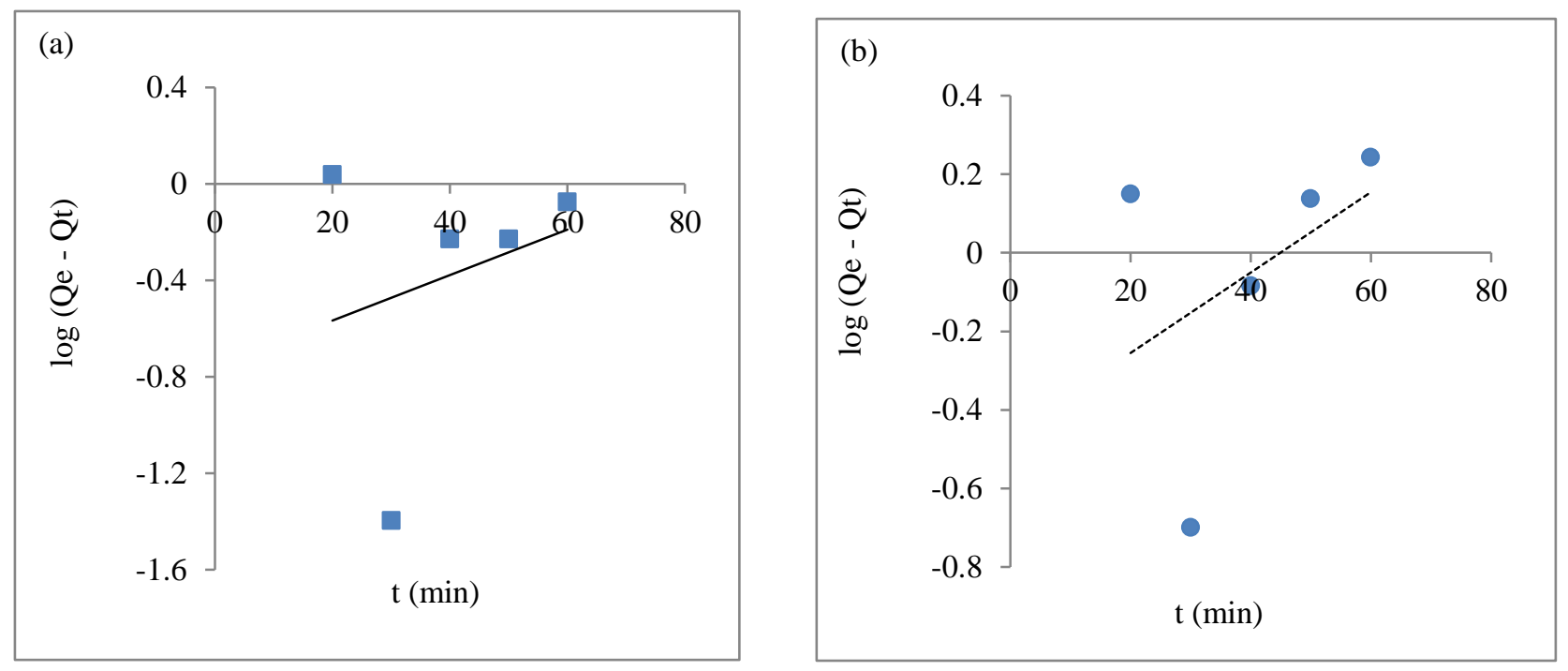

Figure 8: Pseudo - first order kinetic model plot for adsorption of (a) Pb (II) (b) Cr (VI).
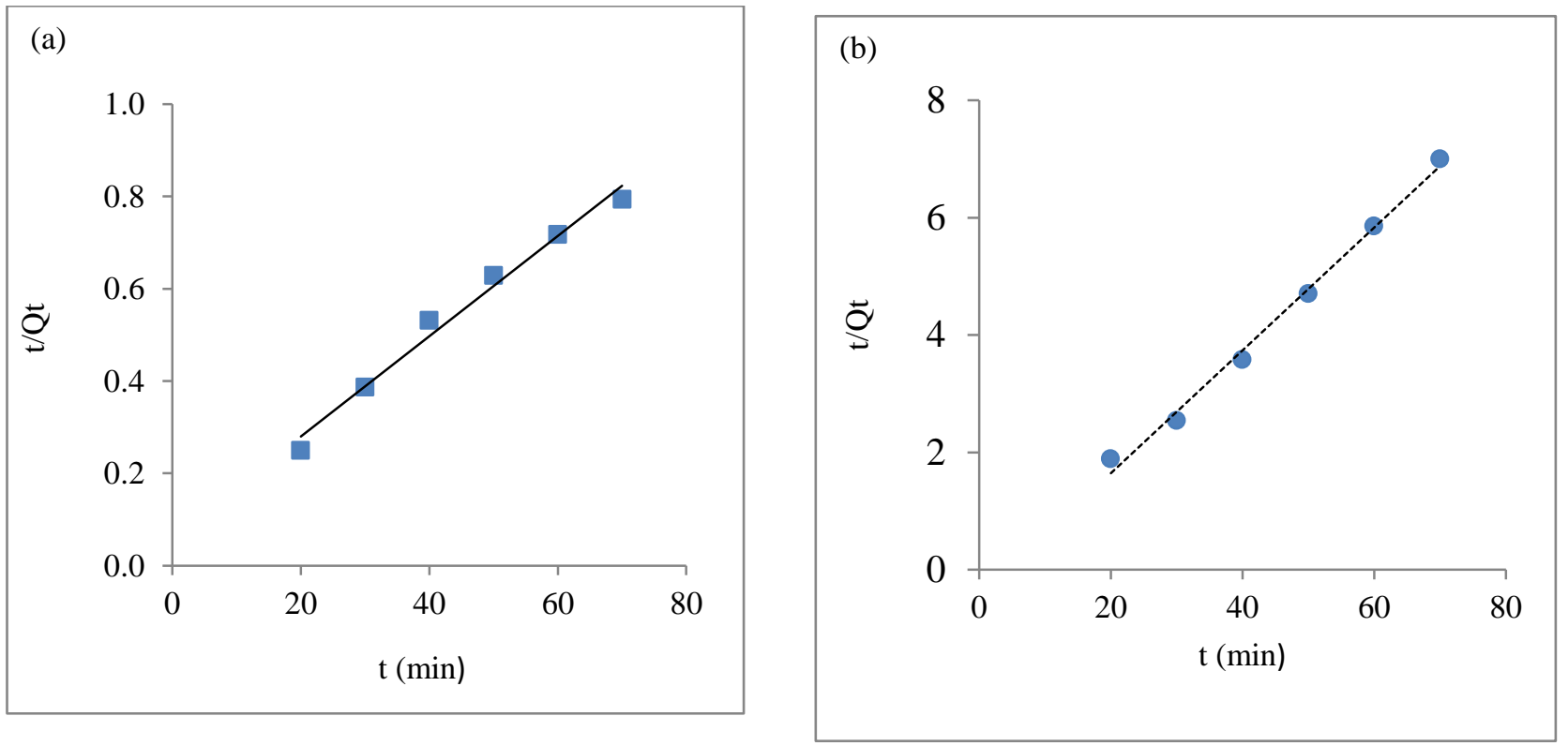

Figure 9: Pseudo - second order kinetic model plot for adsorption of (a) $\mathrm{Pb}$ (II) (b) $\mathrm{Cr}$ (VI). 


\section{CONCLUSIONS}

The prepared sulphuric acid activated flamboyant pod is an efficient and cost-effective adsorbent for the removal of lead and chromium ion from aqueous solutions. The removal efficiency of $\mathrm{Pb}$ (II) and $\mathrm{Cr}$ (VI) was influenced by $\mathrm{pH}$, contact time, initial metal ion concentration and adsorbent dosage. The maximum adsorption was at $\mathrm{pH} 6$, contact time $30 \mathrm{mins}$, the adsorbent dosage of $50 \mathrm{mg}$ with percentage removal of $99.7 \%$ of chromium and $\mathrm{pH} \mathrm{7,} \mathrm{contact} \mathrm{time} 30$ mins, adsorbent dosage $30 \mathrm{mg}$ with percentage removal of $97.2 \%$ of the lead metal ion. Langmuir model showed a better fit to the equilibrium data than the Freundlich isotherm model. The kinetics of adsorption for both metal ions was well represented by pseudo - second order kinetic model.

\section{REFERENCES}

Adebisi, G. A.; Chowdhury, Z. Z. and Alaba, P. A. (2017). Equilibrium, kinetic, and thermodynamic studies of lead ion and zinc ion adsorption from aqueous solution onto activated carbon prepared from palm oil mill effluent. Journal of Cleaner Production, 148: 958-968.

Ali, I.; Mohd, A. and Tabrez, A. K. (2012). Low cost adsorbents for the removal of organic pollutants from wastewater. Journal of environmental management, 113: 170183.

Ali, I. H. and Alrafai, H. (2016). Kinetic, isotherm and thermodynamic studies on biosorption of chromium (VI) by using activated carbon from leaves of Ficus nitida. Chemistry Central Journal, 10(1): 36.

Amarasinghe, B. and Williams, R. (2007). Tea waste as a low cost adsorbent for the removal of $\mathrm{Cu}$ and $\mathrm{Pb}$ from wastewater. Chemical Engineering Journal, 132(1): 299-309.

Auta, M. and Hameed, B. H. (2011). Preparation of waste tea activated carbon using potassium acetate as an activating agent for adsorption of Acid Blue 25 dye. Chemical Engineering Journal, 171(2): 502-509.

Barbooti, M. M. (2015). Simultaneous removal of chromium and lead from water by sorption on Iraqi Montmorillonite. Journal of Environmental Protection, 6(03): 237.

Choudhary, S.; Goyal, V. and Singh, S. (2015). Removal of copper (II) and chromium (VI) from aqueous solution using sorghum roots (S. bicolor): a kinetic and thermodynamic study. Clean Technologies and Environmental Policy, 17(4): 1039-1051.

Clayton, W. (1926). Capillary and colloid chemistry. By Prof. H. Freundlich. Translated by H. Stafford Hatfield: Methuen and Co., Ltd. Journal of the Society of Chemical Industry, 45(44): 797-798.

Dargahi, A.; Golestanifar, H.; Darvishi, P.; Karami, A.; Hasan, S. H.; Poormohammadi, A. and Behzadnia, A. (2016). An investigation and comparison of removing heavy metals (lead and chromium) from aqueous solutions using magnesium oxide nanoparticles. Polish Journal of Environmental Studies, 25(2): 557-562.

Deepa, C. N. and Suresha, S. (2014). Biosorption of lead (II) from aqueous solution and industrial effluent by using leaves of Araucaria cookii: Application of response surface methodology. IOSR Journal of Environmental Science, Toxicology and Food Technology (IOSR-JESTFT), 8(7): 67-79.

Duran, C.; Ozdes, D.; Gundogdu, A. and Senturk, H. B. (2011). Kinetics and Isotherm Analysis of Basic Dyes Adsorption onto Almond Shell (Prunus dulcis) as a Low Cost Adsorbent. Journal of Chemical \& Engineering Data, 56(5): 2136-2147.

Garba, Z. N.; Bello, I.; Galadima, A. and Lawal, A. Y. (2016). Optimization of adsorption conditions using central composite design for the removal of copper (II) and lead (II) by defatted papaya seed. International Journal of Modern Science, 2(1): 20 - 28.

Gupta, V. K. and Ali, I. (2004). Removal of lead and chromium from wastewater using bagasse fly ash - a sugar industry waste. Journal of Colloid and Interface Science, 271(2): 321-328.

Ho, Y. S. and McKay, G. (1999). Pseudo-second order model for sorption processes. Process biochemistry, 34(5): 451-465.

Jimoh, T. O.; Iyaka, Y. A. and Nubaye, M. M. (2012). Sorption Study of Co (II), Cu (II) and Pb (II) ions Removal from Aqueous Solution by Adsorption on Flamboyant Flower (Delonix Regia). American Journal of Chemistry, 2(3): 165170.

Krishna, R. H. and Swamy, A. (2011). Studies on the removal of Ni (II) from aqueous solutions using powder of mosambi fruit peelings as a low cost sorbent. Chemical Sciences Journal, 31(1): 1-13.

Krishnie, M.; Ruella, S.; Evans, T. M.; Maurice, S. O. and Aoyi, O. (2011). Removal of nickel from wastewater using an agricultural adsorbent. Water SA, 37(1): 41-46.

Lagergren, S. and Svenska, B. K. (1898). On the theory of so-called adsorption of dissolved substances. The Royal Swedish Academy of Sciences Document, Band 24: 1-13.

Langmuir, I. (1918). The adsorption of gases on plane surfaces of glass, mica and platinum. Journal of the American Chemical Society, 40(9): 1361-1403.

Lima, L.; Pelosi, B.; Silva, M. and Vieira, M. (2013). Lead and chromium biosorption by Pistia stratiotes biomass. Chemical Engineering Transactions.

Nadeem, R.; Nazir, R. and Nawaz, S. (2014). Biosorption capacity of vegetable waste biomass for adsorption of lead and chromium. Journal of Biodiversity and Environmental Sciences, 5(2): 306-317.

Nethaji, S. and Sivasamy, A. (2014). Removal of hexavalent chromium from aqueous solution using activated carbon prepared from walnut shell biomass through alkali impregnation processes. Clean Technologies and Environmental Policy, 16(2): 361-368.

Olayinka, O. K.; Oyedeji, O. A. and Oyeyiola, A. (2009). Removal of chromium and nickel ions from aqueous solution by adsorption on modified coconut husk. African 
Journal of Environmental Science and Technology, 3(10): $286-293$.

Ozcan, A. S.; Erdem, B. and Ozcan, A. (2004). Adsorption of Acid Blue 193 from aqueous solutions onto Na-bentonite and DTMA-bentonite. J Colloid Interface Sci., 280(1): 44-54.

Qaiser, S.; Saleemi, A. R. and Mahmood Ahmad, M. (2007). Heavy metal uptake by agro based waste materials. Electronic Journal of Biotechnology, 10(3): 409-416.

Qaiser, S.; Saleemi, A. R. and Umar, M. (2009). Biosorption of lead (II) and chromium (VI) on groundnut hull: Equilibrium, kinetics and thermodynamics study. Electronic Journal of Biotechnology, 12(4): 3-4.

Sarma, P. J.; Kumar, R. and Pakshirajan, K. (2015). Batch and Continuous Removal of Copper and Lead from
Aqueous Solution using Cheaply Available Agricultural Waste Materials. Int. J. Environ. Res, 9(2): 635-648.

Vargas, A. M.; Cazetta, A. L.; Garcia, C. A.; Moraes, J. C.; Nogami, E. M.; Lenzi, E.; Costa, W. F. and Almeida, V. C. (2011). Preparation and characterization of activated carbon from a new raw lignocellulosic material: Flamboyant (Delonix regia) pods. Journal of environmental management, 92(1): 178-184.

Yazid, H. and Maachi, R. (2008). Biosorption of lead (II) ions from aqueous solutions by biological activated dates stems. J. Environ. Sci. Technol, 1(4): 201-213.

Zhou, Y.; Zhang, L. and Cheng, Z. (2015). Removal of organic pollutants from aqueous solution using agricultural wastes: a review. Journal of Molecular Liquids, 212: 739762. 